\title{
The cost utility and budget impact of adjuvant racecadotril for acute diarrhea in children in Thailand
}

This article was published in the following Dove Press journal:

ClinicoEconomics and Outcomes Research

17 July 2017

Number of times this article has been viewed

\author{
Tamlyn Anne Rautenberg ${ }^{1,2}$ \\ Ute Zerwes ${ }^{3}$ \\ 'IGES Institut, Berlin, Germany; \\ ${ }^{2}$ Health Economics and HIV/ \\ AIDS Research Division (HEARD), \\ School of Accounting, Economics \\ and Finance, University of KwaZulu \\ Natal, KwaZulu Natal, South Africa; \\ ${ }^{3}$ Assessment in Medicine $\mathrm{GmbH}$, \\ Lörrach, Germany
}

Objective: To evaluate the cost utility and the budget impact of adjuvant racecadotril for the treatment of acute diarrhea in children in Thailand.

Methods: A cost utility model has been adapted to the context of Thailand to evaluate racecadotril plus oral rehydration solution $(\mathrm{R}+\mathrm{ORS})$ versus oral rehydration solution (ORS) alone for acute diarrhea in children $<5$ years old. The decision tree Excel model evaluates the costs and effects (quality-adjusted life years) over a 6-day time horizon from a public health care payer's perspective in Thailand. Deterministic sensitivity analysis and budget impact analysis have been undertaken.

Results: According to the cost utility model, the intervention (R+ORS) is less costly and more effective than the comparator (ORS) for the base case with a dominant incremental costeffectiveness ratio of $-2,481,390 \mathrm{~B}$ for the intervention. According to the budget impact analysis (assuming an increase of 5\% market share for R+ORS over 5 years), the year-on-year reduction for diarrhea as a percentage of the total health care expenditure is $-0.0027 \%$, resulting in potential net cost savings of $-35,632,482$ B over 5 years.

Conclusion: Subject to the assumptions and limitations of the models, adjuvant racecadotril versus ORS alone is potentially cost-effective for children in Thailand and uptake could translate into savings for the Thailand public health care system.

Keywords: economic evaluation, cost utility, decision analysis, health technology assessment

\section{Introduction}

Diarrheal disease remains the second leading cause of death in children under 5 years old and is responsible for around 760,000 deaths in children every year. ${ }^{1}$ In Thailand, the number of children under 5 years with diarrhea was reported at 10,000 cases per 100,000 in $2010 .^{2}$

Acute diarrhea (AD; watery not bloody) is defined as the abrupt onset of three or more loose stools per day. ${ }^{3}$ In young children, the causes may be bacterial or viral; the most common viral cause is rotavirus, which results in infective gastroenteritis. ${ }^{4}$ The Thailand Clinical Guidelines for the Management of Acute Diarrhea recommend Oral Rehydration Therapy (ORT) using Oral Rehydration Solution (ORS) for the prevention and treatment of dehydration. ${ }^{5}$ ORT is defined as the administration of fluid by mouth to prevent or correct dehydration due to diarrhea. ${ }^{6}$ ORS is a combination of dry salts mixed with water which replaces the fluid and electrolytes lost due to diarrhea. ${ }^{6}$ Generally, one sachet of reconstituted ORS makes $240 \mathrm{~mL}$ solution, and it is recommended that children consume ORS after every loose stool for prevention of further dehydration from concurrent loss. ${ }^{7}$ In children with dehydration, dose is
Correspondence: Tamlyn Anne Rautenberg IGES Institute, Friedrichstrasse I80, 10117 Berlin, Germany Tel: +4930230809350 Email rautenbergt@ukzn.ac.za 
weight related and begins at 50 and $100 \mathrm{~mL} / \mathrm{kg}$ for mild and moderate dehydration, respectively. ${ }^{7}$ ORS is a key measure for the treatment of diarrhea with dehydration, but it has questionable impact on the duration or severity of diarrhea. ${ }^{1,5}$ There seems to be limited availability of alternate therapies indicated for infants and children that reduce the duration and severity of diarrhea.

Racecadotril is an antisecretory agent with a unique mechanism of action distinguishing it from other antidiarrheal agents. Racecadotril "decreases the intestinal hypersecretion of water and electrolytes induced by the cholera toxin or inflammation, and does not have effects on basal secretory activity. Racecadotril exerts rapid antidiarrheal action, without modifying the duration of intestinal transit." ${ }^{\text {" Racecado- }}$ tril's safety profile, ${ }^{9}$ clinical efficacy ${ }^{10-17}$ and synthesis of efficacy $^{18,19}$ have been described elsewhere. Racecadotril has been commercially available in Thailand since 2008 and is not included in the National List of Essential Medicines. Racecadotril is licensed as a complementary symptomatic treatment of AD in infants (older than 3 months) and children, together with oral rehydration (ORS). ${ }^{8}$

In Thailand, the commendable work of the Health Intervention and Technology Assessment Program (HiTAP) has seen expansion of the use of health technology assessment (HTA) to assist with difficult decisions in the universal coverage of different health care drugs and interventions. ${ }^{20}$ In the context of rationing of health care delivery, the Thailand HTA Guidelines (2014) confirm the need for the use of economic evidence in decision making and, in particular, for Thailand's National List of Essential Medicines. ${ }^{21,22}$ A previous cost utility study evaluated the use of racecadotril in a developed country setting; however, to date, no such studies have evaluated the cost utility of racecadotril in Thailand. ${ }^{23}$ Literature suggests that if identical predetermined methods are used for economic evaluation as part of HTA, then it may be possible to apply the results of such analyses to multiple countries. ${ }^{24}$ However, there is still variation in the methodological requirements for HTA in different countries. This is partly because countries are at different evolutionary stages of incorporating HTA into reimbursement processes. There also remains some doubt whether economic evaluations can be applied across countries with different income group status and differently composed health care systems. As a result, there is currently still a need for model adaptations. The objective of this analysis was to evaluate the cost utility and budget impact of racecadotril in the context of the Thailand health care setting and, where possible, in accordance with the recommendations of the Thai HTA Guidelines..$^{25-31}$

\section{Methods \\ Cost utility model}

The original Racecadotril for Acute Watery Diarrhea (RAWD) model is the basis for the model adaptation for Thailand presented in this paper (hereafter referred to as the model). ${ }^{23}$ RAWD was developed according to the reference case set out by the UK National Institute for Health and Care Excellence (NICE). The original RAWD model has been adapted for Thailand. The model is programmed in Microsoft Excel (Microsoft Corporation, Redmond, WA, USA). The analysis takes the perspective of the public health care setting in Thailand and focuses on patients under universal coverage. The intervention in the model is adjuvant racecadotril ( $\mathrm{R}+\mathrm{ORS})$. Racecadotril has been described and evaluated in clinical studies in combination with ORS for AD. The comparator in the model is ORT and, more specifically, ORS, according to the recommendations of the Thailand Clinical Guideline for Diarrhea. ${ }^{5}$

The time horizon of the model is 6 days based on the rationale that $\mathrm{AD}$ is self-limiting around 5-7 days. ${ }^{32}$ It is considered that in view of the acute nature of $\mathrm{AD}$, all relevant costs and consequences of one episode of AD will occur within 6 days. ${ }^{28}$ Due to the short time horizon, no discounting has been applied. ${ }^{28}$ The target population is children under 5 years with $\mathrm{AD}$ due to any cause, because there is clinical evidence to support the use of racecadotril in this population. ${ }^{10-16}$ Outcomes are measured as health effects, in particular, quality-adjusted life years (QALYs) in children.

\section{Model structure and adaptations}

The decision tree structure of the model did not need to be changed; however, the nomenclature was revised to reflect the clinical pathways in Thailand. In Thailand, children generally present in the outpatient setting, for example, a primary health care center or the outpatient department of a public hospital. Therefore, in the model, for the standard of care pathway, it is assumed that within the first 24 hours of the onset of diarrhea (T0-T24), the affected child will be given standard of care, which is ORS. ${ }^{5}$ It is further assumed that if the diarrhea is unresolved during the subsequent 48-hour period $(\mathrm{T} 24<\mathrm{T} 72)$, the child will be taken back for a followup visit to the outpatient department. At this point in time (T72), depending on the clinical status and any evidence of dehydration, the child will either be admitted to a secondary care hospital or continue on ORS ( $\leq \mathrm{T} 144)$. The intervention pathway representing the addition of adjuvant racecadotril to ORS alone follows the same assumptions as the standard of care pathway described above. The structure of the model is shown in Figure 1. 


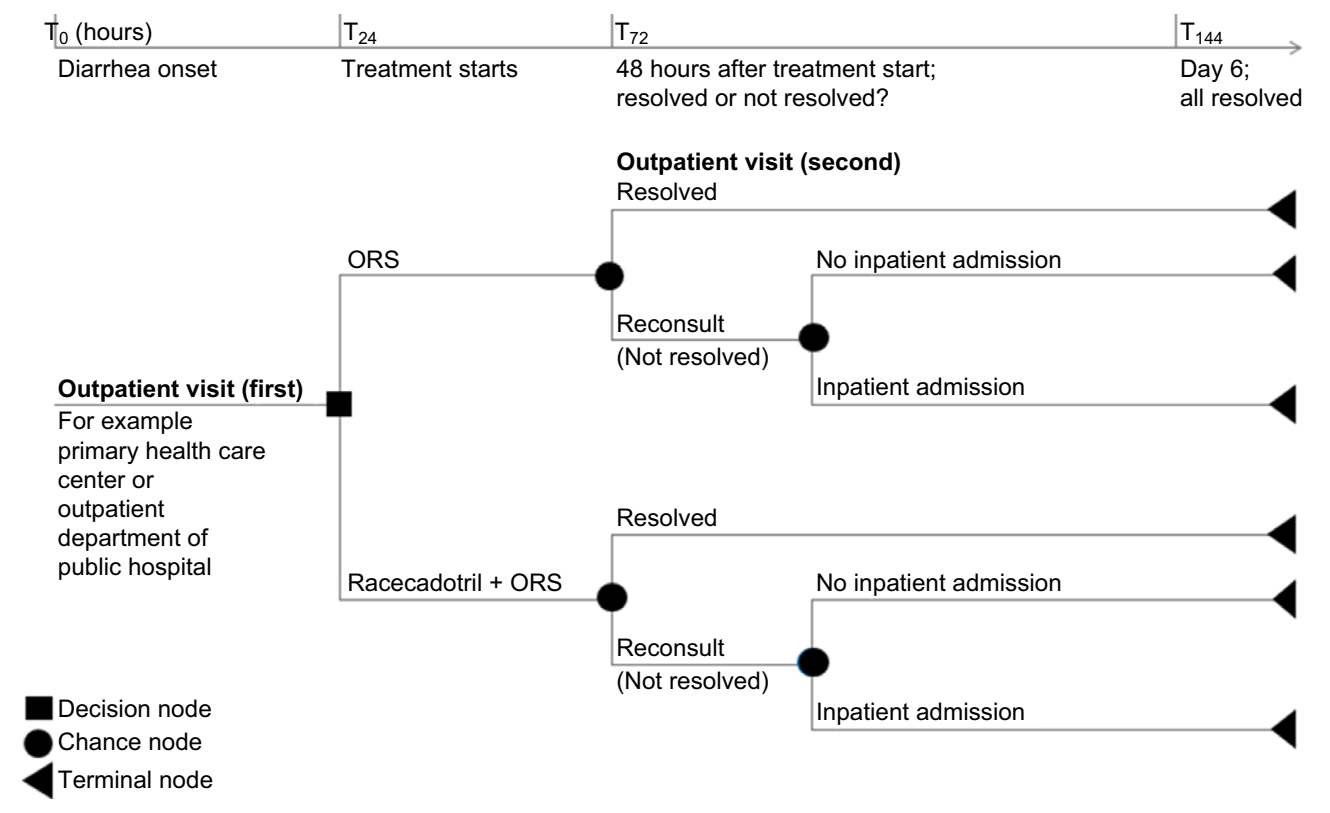

Figure I Cost utility decision tree model structure adaptation for Thailand. Abbreviations: ORS, oral rehydration solution; T, time.

Clinical efficacy, adverse event frequency and utility data remained the same in the model adaptation, and have been described in detail previously and elaborated further in the "Discussion" section. ${ }^{23}$ Cost data from sources in Thailand were used to populate the model, as shown in Table 1.

Thailand data were used to calculate the average cost of an adverse event. The average cost of an episode of vomiting, fever and drug allergy was calculated. The average included $50 \%$ of patients being charged the service cost $(50 \mathrm{~B})$ and $50 \%$ not being charged the service cost. The calculation of the cost of adverse events in Thailand is shown in Table 2. ${ }^{33,36}$

The RAWD model assumptions have been previously described and remain unchanged. ${ }^{23}$ For a tabulation of all base case parameters, please refer to Table S1.

\section{Budget impact model}

A budget impact model was programmed in Microsoft Excel (Microsoft Corporation). A calculation of the estimated number of children with moderate diarrhea who would follow the clinical pathway described in the cost utility model was made based on the total population in Thailand, ${ }^{39}$ the total number of children under 5 years $^{39}$ and the incidence of diarrhea in under-fives. ${ }^{2}$ Further to this, according to data from December 2016, in Thailand, 58\% of all under-fives with diarrhea have ORS. ${ }^{40}$ Additionally, a systematic review of the duration and severity of diarrhea showed that in children, $64.8 \%$ of diarrhea cases can be classed as mild (do not seek care 2 weeks prior to survey), $34.7 \%$ as moderate (seek care 2 weeks prior to survey) and $0.5 \%$ as severe. ${ }^{41}$ The budget impact model, therefore, assumes that of the $58 \%$ of children with diarrhea given ORS, $34.7 \%$ have moderate diarrhea and are eligible for the treatment pathway shown in Figure 1. The resultant cohort of children eligible for R+ORS is, therefore, 74,597, as shown in Table 3.

\section{Results \\ Cost utility model}

For the base case analysis, R+ORS versus ORS alone, the average cost savings per child is $-1,910.67 \mathrm{~B}$ for an average gain of 0.00077 QALYs. The upfront increase in drug cost for $\mathrm{R}+\mathrm{ORS}(+169.38 \mathrm{~B})$ is offset by savings due to reduction in outpatient $(-45.63 \mathrm{~B})$, inpatient $(-2,033.62 \mathrm{~B})$ and adverse event $(-0.80 \mathrm{~B})$ costs, which results in a total net potential savings of $-1,910.67 \mathrm{~B}$ per child per diarrhea episode for the Thailand public health care system. These results are summarized in Table 4.

According to the cost utility model, $\mathrm{R}+\mathrm{ORS}$ is less costly and more effective than ORS alone. The incremental costeffectiveness ratio (ICER) is $-2,481,390 \mathrm{~B}$, which means that the ICER for R+ORS is dominant over ORS alone. The ICER is shown in Figure 2.

\section{Sensitivity analysis}

Deterministic sensitivity analysis was undertaken, whereby every base case model input parameter was varied sequentially by $20 \%$ upper and lower estimates (unless otherwise 
Table I Thailand cost data model inputs and cost calculation

\begin{tabular}{|c|c|c|c|}
\hline Description & Value & Unit & Source \\
\hline \multicolumn{4}{|l|}{ Racecadotril + ORS } \\
\hline Recommended dose/administration & 1.5 & $\mathrm{mg} / \mathrm{kg}$ & Abbott Laboratories ${ }^{33}$ \\
\hline Average weight of child $(\mathrm{kg})$ & 12.9 & $\mathrm{~kg}$ & $\mathrm{NSO},{ }^{34} \mathrm{WHO}^{35}$ \\
\hline Total dose per administration & 19.4 & $\mathrm{mg}$ & Model calculation (no source) \\
\hline Number of administrations per day & 3 & $\mathrm{n}$ & Abbott Laboratories ${ }^{33}$ \\
\hline Total daily dose & 58.05 & $\mathrm{mg}$ & Model calculation (no source) \\
\hline Number of milligrams per sachet & 30 & $\mathrm{mg}$ & Abbott Laboratories ${ }^{33}$ \\
\hline Number of sachets required (rounded up to nearest whole sachet) & 1.94 & $\mathrm{n}$ & Model calculation (no source) - rounded up to 2 \\
\hline Cost per sachet & 26.78 & B & Drug and Medical Supply Information Center ${ }^{36}$ \\
\hline Total daily cost racecadotril & 53.56 & B & Model calculation (no source) \\
\hline Total daily cost racecadotril + ORS & 58.18 & $B$ & Model calculation (no source) \\
\hline \multicolumn{4}{|l|}{ ORS } \\
\hline Recommended dose/administration & 240 & $\mathrm{~mL}$ & Pharaonia Pharmaceuticals (Pharo Pharma) ${ }^{37}$ \\
\hline Number of sachets & 1 & $\mathrm{n}$ & Pharaonia Pharmaceuticals (Pharo Pharma) \\
\hline Stool frequency & $3 *$ & $\mathrm{n}$ & Model assumption (no source) \\
\hline Total daily dose & 3 & $\mathrm{n}$ & Model calculation (no source) \\
\hline Average weighted cost per sachet & 1.54 & $B$ & Pharaonia Pharmaceuticals (Pharo Pharma) ${ }^{37}$ \\
\hline Total daily cost ORS & 4.62 & B & Model calculation (no source) \\
\hline Average cost per primary health care center visit (normal hours) & 142.60 & B & Expert opinion ${ }^{\mathrm{a}}$ \\
\hline National average nonelective inpatient stay (short) & $2,824.00$ & B & Sutra et $\mathrm{al}^{2}$ \\
\hline
\end{tabular}

Notes: The average weight for a child under the age of five in Thailand has been calculated as follows: according to the Multiple Indicator Cluster Survey for Thailand 20 I2, $9.2 \%$ of children in Thailand under 5 years are moderately underweight ( -2 SD), $2.1 \%$ are severely underweight ( -3 SD) and II\% are overweight (assumed to be +2 SD). ${ }^{34}$ Based on this, it was assumed that the remaining children are median weight for age. The average weight, therefore, is $12.9 \mathrm{~kg}$ for a $0-60-$ months old child in Thailand. *Note that three stools is a minimum, which conservatively estimates (underestimates) the cost of ORS alone for the purpose of the analysis. It is more likely that five sachets will be used if

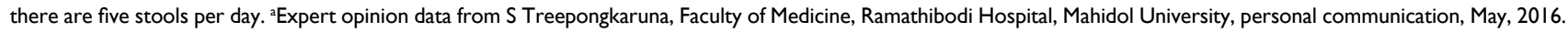
Abbreviations: NSO; National Statistical Office; ORS, oral rehydration solution; SD, standard deviation; WHO, World Health Organization

Table 2 Calculation of average cost of treatment per child per adverse event (R+ORS and/or ORS alone)

\begin{tabular}{|c|c|c|c|c|c|c|}
\hline $\begin{array}{l}\text { Adverse event- } \\
\text { severity }\end{array}$ & Treatment & $\begin{array}{l}\text { Drug/admission } \\
\text { cost }(B) \text { (reference) }\end{array}$ & $\begin{array}{l}\text { Proportion } \\
\text { of all adverse } \\
\text { events, \% }\end{array}$ & $\begin{array}{l}\text { Proportion } \\
\text { cost }\end{array}$ & $\begin{array}{l}\text { Average } \\
\text { (- service } \\
\text { cost) } B\end{array}$ & $\begin{array}{l}\text { Average } \\
\text { (+ service } \\
\text { cost) } B\end{array}$ \\
\hline Vomiting - mild & Domperidone & $5.77^{36}$ & $47.5^{\mathrm{a}}$ & 2.74 & 102.59 & 152.59 \\
\hline Vomiting - moderate & Ondansetron IV & $15.89^{36}$ & $47.5^{\mathrm{a}}$ & 7.55 & & \\
\hline Vomiting - severe & $\begin{array}{l}\text { Gastroenteritis in children } \\
<10 \text { years no } \mathrm{cc}\end{array}$ & $1,846 * 45$ & $5.0^{38}$ & 92.30 & & \\
\hline $\begin{array}{l}\text { Average cost per } \\
\text { episode of vomiting }\end{array}$ & & & & & 127.59 & \\
\hline Fever - mild & $\begin{array}{l}\text { Paracetamol (two bottles at } \\
6.90 \text { B) }\end{array}$ & $13.8^{36}$ & $45^{\mathrm{a}}$ & 6.21 & 197.02 & 247.02 \\
\hline Fever-moderate & $\begin{array}{l}\text { Paracetamol (two bottles at } \\
6.90 \mathrm{~B})\end{array}$ & $13.8^{36}$ & $45^{\mathrm{a}}$ & 6.21 & & \\
\hline Fever - severe & $\begin{array}{l}\text { Gastroenteritis in children } \\
<10 \text { years no } \mathrm{cc}\end{array}$ & $\mathrm{I}, 846^{*, 45}$ & $10^{\mathrm{a}}$ & 184.60 & & \\
\hline $\begin{array}{l}\text { Average cost per } \\
\text { episode of fever }\end{array}$ & & & & & 222.02 & \\
\hline Drug allergy - mild & Hydroxyzine & $8.92^{36}$ & $45^{\mathrm{a}}$ & 4.01 & 442.38 & 492.38 \\
\hline $\begin{array}{l}\text { Drug allergy - } \\
\text { moderate }\end{array}$ & Hydroxyzine & $8.92^{36}$ & $45^{\mathrm{a}}$ & 4.01 & & \\
\hline Drug allergy - severe & $\begin{array}{l}\text { Gastroenteritis in children }<10 \\
\text { years, moderate complications }\end{array}$ & $4,344 * *, 45$ & $10^{\mathrm{a}}$ & 434.35 & & \\
\hline $\begin{array}{l}\text { Average cost per } \\
\text { episode of drug allergy }\end{array}$ & & & & & 467.38 & \\
\hline
\end{tabular}


constrained by maximum and minimum values). The model is most sensitive to the quality of life (QoL) of a "well" person $( \pm 175 \%)$; a $20 \%$ change in this variable can overturn the results of the model (these results are not included in the tornado diagram). The results are responsive to the QoL of a child in the inpatient setting $(\leq 45 \%)$. The next most influential parameter is the proportion of children on R+ORS whose diarrhea resolves at 48 hours $(\leq 28 \%)$. Following this, the results are sensitive to the cost of an inpatient stay $(\leq 22 \%)$, the proportion of children on ORS referred for inpatient stay at 48 hours $(\leq 18 \%)$ and the average QoL of a child in the outpatient setting $(\leq 14 \%)$. For all other parameters, a $20 \%$ change in value results in $<5 \%$ change in results. A tornado diagram fulfills the requirements of the Thailand HTA Guidelines $^{31}$ and is shown in Figure 3.

\section{Budget impact model}

Based on the calculated cohort, an increase of $5 \%$ in the market share of R+ORS over five consecutive years means a reduction in the total health care budget of $0.0027 \%$ each consecutive year, resulting in a total potential cost savings of $-35,632,482 \mathrm{~B}$ over a 5-year period, as shown in Table 5.

Figure 4 shows the changes in diarrhea as a percentage of total health care expenditure over a 5-year period corresponding to an increase of 5\% market share for R+ORS.

Evaluating the sensitivity of the budget impact results to the increase in market share of $\mathrm{R}+\mathrm{ORS}$ shows that an increase

Table 3 Budget impact calculation for the population cohort eligible for R+ORS and/or ORS alone

\begin{tabular}{|c|c|c|}
\hline Description & Total & Reference \\
\hline Total population (n) & $66,785,000$ & Unice $^{39}$ \\
\hline Total children $<5$ years $(n)$ & $3,706,500$ & Unicef ${ }^{39}$ \\
\hline $\begin{array}{l}\text { Incidence of diarrhea }<5 \text { years (per } \\
100,000)\end{array}$ & $10 \%$ & Sutra et $\mathrm{al}^{2}$ \\
\hline $\begin{array}{l}\text { Number of children }<5 \text { years with } \\
\text { diarrhea }(n)\end{array}$ & 370,650 & $\begin{array}{l}\text { Model calculation } \\
\text { (no reference) }\end{array}$ \\
\hline $\begin{array}{l}\text { Percentage of children with diarrhea } \\
\text { having ORS }\end{array}$ & $58 \%$ & Unicef $^{40}$ \\
\hline Percentage of moderate diarrhea (\%) & $34.7 \%$ & Lamberti $^{41}$ \\
\hline $\begin{array}{l}\text { Number of children eligible for } \\
\text { treatment }(n)\end{array}$ & 74,597 & $\begin{array}{l}\text { Model calculation } \\
\text { (no reference) }\end{array}$ \\
\hline
\end{tabular}

of $2.5 \%$ (i.e., $2.5 \%$ for year $1,2,3,4,5$ ), $7.5 \%$ and $10 \%$ in the market share for R+ORS over five consecutive years results in total potential cumulative cost savings of $-17,816,241 \mathrm{~B}$, $-53,448,710 \mathrm{~B}$ and $-71,264,947 \mathrm{~B}$, respectively.

\section{Discussion and limitations}

To some degree, the analysis is constrained by the limited availability of country-specific data for Thailand in the public domain. For example the most accurate estimate of cost of an outpatient visit could be sourced from the National Health Security Office, however as a proxy for this in the model, the cost of an outpatient visit was taken from one district hospital. With respect to calculation of the drug cost, the model considers the drug cost of actual sachets used for each regimen and does not include the effects of wastage or noncompliance. Calculation of the dose of racecadotril is based on the average weight of children $<5$ years in Thailand, which was estimated at $12.9 \mathrm{~kg}$. ${ }^{34,35}$ The model rounds up the number of racecadotril sachets; therefore, the calculation in this analysis is based on using two sachets of racecadotril per day. Due to the roundup, the results hold true for the range of average weight $6.7 \leq 13.3 \mathrm{~kg}$

According to the Thailand HTA Guidelines, a societal perspective is the method of choice for economic evaluation; however, there is limited evidence on the direct nonmedical and indirect costs specific to Thailand, and therefore, a health care payer perspective was adopted. ${ }^{27}$ In

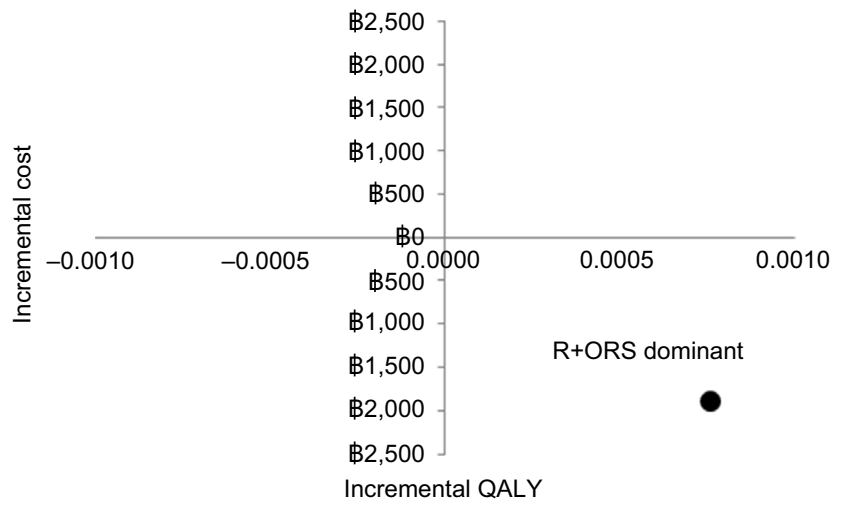

Figure 2 Incremental cost-effectiveness ratio on the cost utility plane. Abbreviations: ORS, oral rehydration solution; QALY, quality-adjusted life year; $R$, racecadotril.

Table 4 Mean cost per patient for drugs, outpatient care, inpatient care and adverse events for R+ORS versus ORS alone

\begin{tabular}{llll}
\hline Mean cost per patient B & ORS (comparator) B & Racecadotril + ORS (intervention) B & Difference B \\
\hline Drug cost & 15.81 & 185.20 & 169.38 \\
Outpatient care & 248.12 & 202.49 & -45.63 \\
Inpatient care & $2,250.67$ & 217.05 & $-2,033.62$ \\
Adverse events & 3.39 & 2.59 & -0.80 \\
Total mean cost per patient & $2,518.00$ & 607.33 & $-1,910.67$ \\
\hline
\end{tabular}

Abbreviations: ORS, oral rehydration solution; $R$, racecadotril. 


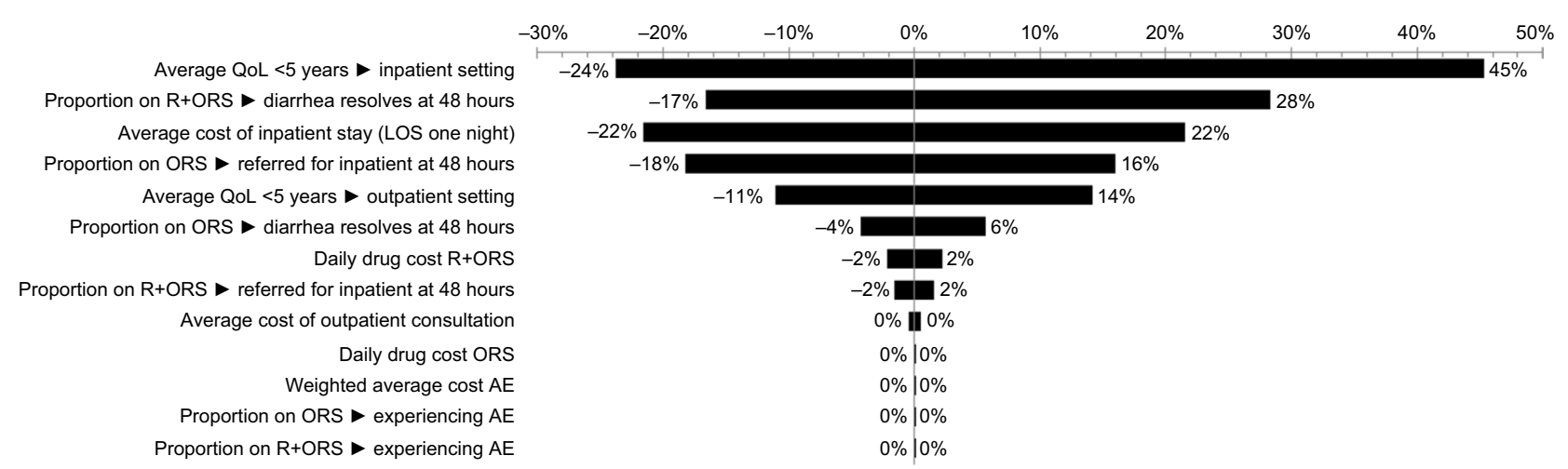

Figure 3 Tornado diagram of deterministic sensitivity analysis.

Notes: Note that due to scale, the QoL parameter of a "well" person is not shown in the tornado diagram; a $20 \%$ change in this parameter results in I75\% change in the model results.

Abbreviations: AE, adverse event; LOS, length of stay; ORS, oral rehydration solution; QoL, quality of life; R, racecadotril.

Table 5 Budget impact results year 0 (current) to year 5, assuming 5\% increase in market share for $\mathrm{R}+\mathrm{ORS}$

\begin{tabular}{|c|c|c|c|c|c|c|c|}
\hline \multirow[t]{2}{*}{ Year } & \multicolumn{2}{|c|}{ ORS alone } & \multicolumn{2}{|l|}{ R+ORS } & \multirow{2}{*}{$\begin{array}{l}\text { Total } \\
\text { expenditure }(B)\end{array}$} & \multirow{2}{*}{$\begin{array}{l}\text { Diarrhea as \% } \\
\text { of total public } \\
\text { health care } \\
\text { budget }\end{array}$} & \multirow{2}{*}{$\begin{array}{l}\text { Cumulative } \\
\text { reduction in tota } \\
\text { expenditure }(B)\end{array}$} \\
\hline & $\begin{array}{l}\text { Market } \\
\text { share, \% }\end{array}$ & $\begin{array}{l}\text { Cohort } \\
\text { expenditure }(B)\end{array}$ & $\begin{array}{l}\text { Market } \\
\text { share }\end{array}$ & $\begin{array}{l}\text { Cohort } \\
\text { expenditure (B) }\end{array}$ & & & \\
\hline Year 0 & 100 & $187,835,249$ & $0 \%$ & 0 & $187,835,249$ & 0.0700 & -0 \\
\hline Year I & 95 & $178,443,486$ & $5 \%$ & $2,265,266$ & $180,708,752$ & 0.0674 & $-7,126,496$ \\
\hline Year 2 & 90 & $169,05 \mid, 724$ & $10 \%$ & $4,530,532$ & $173,582,256$ & 0.0647 & $-14,252,993$ \\
\hline Year 3 & 85 & $|59,659,96|$ & $15 \%$ & $6,795,798$ & $166,455,759$ & 0.0620 & $-21,379,489$ \\
\hline Year 4 & 80 & $150,268,199$ & $20 \%$ & $9,061,064$ & $159,329,263$ & 0.0594 & $-28,505,986$ \\
\hline Year 5 & 75 & $140,876,436$ & $25 \%$ & $11,326,330$ & $152,202,766$ & 0.0567 & $-35,632,482$ \\
\hline
\end{tabular}

Abbreviations: ORS, oral rehydration solution; $R$, racecadotril.

keeping with this, the direct medical costs were included in the model and the direct nonmedical and indirect costs were excluded. This was also a pragmatic decision, since it eased the adaptation of the model (the original RAWD model did not include the latter) and the lack of countryspecific direct nonmedical cost data for Thailand. No startup costs were relevant. ${ }^{27}$

Previously, the selection of clinical data for the model was done in a systematic and transparent way and the rationale for evidence selection has been previously described. ${ }^{23}$ If a bespoke model had been developed for Thailand, a review of clinical efficacy data (such as previously described) would have been undertaken. However, there is no new clinical efficacy data available since the original model was published; therefore, it is acceptable that this data has remained the same for the adaptation. As before, the reader should consider that the nine studies used for the Lehert meta-analysis ${ }^{18}$ (and in the model) were undertaken in France (two), ${ }^{10,11}$ Spain (two), ${ }^{12,13}$ Peru, ${ }^{14}$ India,,${ }^{15}$ Mexico (two studies) ${ }^{16}$ and Guatemala. ${ }^{17}$ The external validity of the clinical data will depend on how closely the above countries represent the health care system in Thailand. Similarly, there is no new data relating to adverse events; therefore, the clinical efficacy and adverse event data are subject to the same limitations as previously described. ${ }^{23}$ The adverse event data comes from 34 countries worldwide.

The utility data in the model comes from a study done in the UK population. The study measures QALYs by time trade off method with EuroQol five dimensions questionnaire (EQ-5D) in compliance with the Thailand Guidelines for HTA recommendations. ${ }^{42}$ It is probable that the utility of a child with diarrhea in Thailand is different from the utility of a child with diarrhea in the UK in part due to the prevalence of infectious disease and comorbidities in Thailand. If we assume that the QoL of a child under five with diarrhea in Thailand is worse than in the UK, then the gap between diarrheic and "well" is larger and the QALY gain would, therefore, be greater. If anything, should country-specific data for Thailand become available, then the cost utility of $\mathrm{R}+\mathrm{ORS}$ versus ORS alone would probably be higher.

The Thailand Guidelines for HTA recommend cost utility analysis as the economic evaluation method of choice where the prescribed outcome is QALYs; therefore, this criterion has been satisfied in this analysis. ${ }^{25,26}$ However, 
口ORS \% -Racecadotril \%

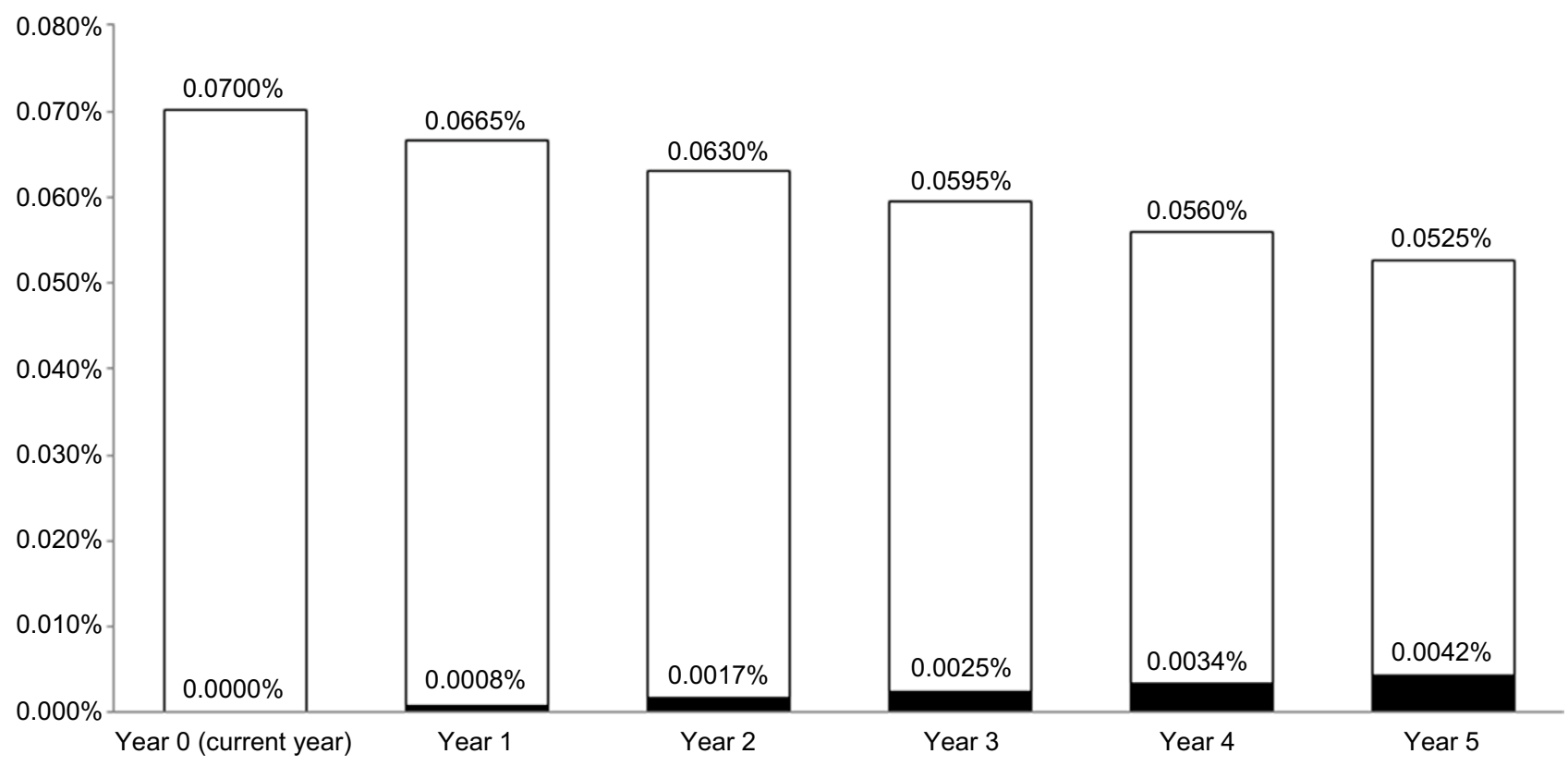

Figure 4 Percentage overall health expenditure current year ( 0 ) to year 5 for ORS and R+ORS Abbreviations: ORS, oral rehydration solution; $R$, racecadotril.

the model results are substantially sensitive to the QoL of a "well" person and a child with diarrhea in the inpatient and outpatient settings, respectively. The cost utility model results show a gain of 0.0077 QALYs for R+ORS; however, it is debatable whether this difference is significant for children with diarrhea or for payers. Generally, in economic evaluation, a notable incremental increase in QoL justifies an incremental cost to the payer. Although in this analysis there is no notable difference in QoL, there is also no incremental cost. However, due to the sensitivity of the model to the QoL parameters, let us assume that there is no gain in QALY and that the outcomes for both pathways are equivalent. This situation would warrant a cost comparison (minimization) analysis. When the QoL values in the model are set to equal, the model becomes a cost comparison model and the average potential cost savings per child treated with $\mathrm{R}+\mathrm{ORS}$ versus ORS alone is $-1,910.67 \mathrm{~B}$. In this case, the model is most sensitive to the proportion of children on R+ORS and ORS alone, respectively, whose diarrhea resolves at 48 hours. This is because when the diarrhea resolves, the child does not present again to the outpatient clinic, resulting in a difference in the total cost of the outpatient visits $(-45.63 \mathrm{~B})$. Let us also consider that the model results are largely unaffected by the frequency and cost of adverse events since clinical studies show that there is no significant difference between adverse events in R+ORS versus ORS. When these parameters are "neutralized" in the model (i.e., the model values are made equal for these parameters), then the remaining influential variables (cost drivers) are the average cost of an inpatient stay and the proportion of children on ORS and R+ORS, respectively, referred for inpatient stay. The crux of the decision for decision makers in Thailand is, therefore, the difference in inpatient stays between the two pathways and the total cost of an inpatient stay.

Probabilistic sensitivity analysis is the preferred method of handling uncertainty. ${ }^{31}$ Unfortunately, the project budget did not allow for adaptation of the probabilistic component of the cost utility model. In its absence, considering that the fundamental structure of the model did not change, reference to the previous probabilistic analysis is highly relevant. ${ }^{23}$

The original RAWD model evaluated the cost utility of racecadotril in the UK setting. In the UK, racecadotril (Hidrasec) received a marketing authorization in September 2011 and has been commercially available since October 2012 . The UK NICE clinical guideline on diarrhea and vomiting in children under 5 was published in 2009 prior to licensing and cost utility analysis. ${ }^{23,43}$ NICE released an Evidence Summary: New Medicine, which recommends that "local decision makers will need to consider the available evidence when making decisions about using racecadotril". In the UK, the addition of racecadotril to national formulary is probably not critical, considering the oral vaccination program against rotavirus ${ }^{4}$ and the relatively low child mortality due to diarrhea (diarrhea as the cause of death: 13 in 2015 in the 
UK versus 260 in 2015 in Thailand). ${ }^{44}$ However, in Thailand, inclusion of racecadotril on the National List of Essential Medicines may have an important impact on child health, mortality and health payer budget, respectively.

\section{Conclusion}

Subject to the assumptions and limitations of the model, adjuvant racecadotril versus ORS alone is potentially costeffective in the Thailand public health care context. Budget impact analysis shows that this potentially translates into savings for the Thailand public health care system.

\section{Acknowledgments}

The authors thank Professor Suporn Treepongkaruna, MD, Faculty of Medicine, Ramathibodi Hospital, Mahidol University, Bangkok, Thailand, for her expert opinion and clinical expertise. They also thank Abbott affiliates in Thailand for providing data for the model. IGES Institut $\mathrm{GmbH}$ and Assessment in Medicine GmbH were contracted by Abbott for the model adaptation and publication. This adaptation of the original RAWD model for Thailand and this publication were sponsored by Abbott Laboratories.

\section{Author contributions}

TAR adapted the model to Thailand. UZ performed literature searches for model inputs and validated the cost utility and budget impact model adaptations. Both authors contributed toward data analysis, drafting and critically revising the paper, gave final approval of the version to be published, and agree to be accountable for all aspects of the work.

\section{Disclosure}

TAR is a freelance health economics consultant and was contracted by the IGES Institut for this work. UZ is employed by Assessment in Medicine GmbH. The authors had the final decision regarding manuscript content and report no other conflicts of interest in this work.

\section{References}

1. World Health Organization. Diarrhoeal Disease; 2013. Available from: http://www.who.int/mediacentre/factsheets/fs330/en/. Accessed May $25,2016$.

2. Sutra S, Kosuwon P, Chirawatkul A, Thepsuthammarat K. Burden of acute, persistent and chronic diarrhea, Thailand, 2010. J Med Assoc Thai. 2012;95(Suppl 7):S97-S107.

3. Thielman NM, Guerrant RL. Clinical practice. Acute infectious diarrhea. N Engl J Med. 2004;350(1):38-47.

4. National Institute for Health and Care Excellence (NICE). Acute diarrhoea in children: racecadotril as an adjunct to oral rehydration: Evidence summary; 2013. Available from: http://www.nice.org.uk/guidance/esnm12. Accessed March 15, 2016.
5. Royal College of Pediatricians of Thailand. Guideline for the Management of Acute Diarrhea. Available from: www.thaipediatrics.org/ cpg_file/1.doc. Accessed June 24, 2016.

6. World Health Organisation. Oral Rehydration Salts Production of the new ORS; 2006. Available from: http://apps.who.int/iris/bitstream/10,665/ 69,227/1/WHO_FCH_CAH_06.1.pdf. Accessed March 21, 2017.

7. World Gastroenterology Organisation Global Guidelines. Acute Diarrhea in Adults and Children: a Global Perspective; 2012. http://www. worldgastroenterology.org/UserFiles/file/guidelines/acute-diarrheaenglish-2012.pdf. Accessed April 10, 2017.

8. Hidrasec Paediatric. Summary of Product Characteristics. Thailand: Abbott Laboratories; 2015.

9. Baumer P, Joulin Y. Pre- and postmarketing safety profiles of Racecadotril sachets, a "new" antidiarrhoeal drug. J Pediatr Gastroenterol Nutr. 2009;48(Suppl 3):E99.

10. Cezard JP, Duhamel JF, Meyer M, et al. Efficacy and tolerability of racecadotril in acute diarrhea in children. Gastroenterology. 2001;120(4):799-805.

11. Cojocaru B, Bocquet N, Timsit S, et al. Effet du racécadotril sur le recours aux soins dans le traitement des diarrhées aiguës du nourrisson et de l'enfant [Effect of racecadotril in the management of acute diarrhea in infants and children]. Arch Pediatr. 2002;9(8):774-779. French.

12. Santos M, Maranon R, Miguez C, Vazquez P, Sanchez C. Use of racecadotril as outpatient treatment for acute gastroenteritis: a prospective, randomized, parallel study. J Pediatr. 2009;155(1):62-67.

13. Alvarez Calatayud E, Pinei Simon G, Taboada Castro L, et al. Efectividad de racecadotrilo en el tratamiento de la gastroenteritis aguda [The effectiveness of racecadotril in the treatment of acute gastroenteritis]. Acta Pediatr.Esp. 2009;67(3):117-122. Spanish.

14. Salazar-Lindo E, Santisteban-Ponce J, Chea-Woo E, Gutierrez M. Racecadotril in the treatment of acute watery diarrhea in children. N Engl J Med. 2000;343(7):463-467.

15. Savita MR, Mysore GMC. Racecadotril - a novel drug for the treatment of acute watery diarrhea in Indian children; 2006. Available from: http:// www.pediatriconcall.com/fordoctor/conference_abstracts/racecadotrial. asp. Accessed December 1, 2014.

16. Gutierrez-Castrellon P, Acosta-Bastidas M, Llamosas Gallardo B, et al. Ensayo clinico aleatorizado y analisis farmacoeconomico del impacto de racecadotrilo (Hidrasec ${ }^{\circledR}$ ) como coadyuvante en el tratamiento de la gastroenetritis aguda sobre la reduccion de los gastos hospitalierios relacionados en lactantes menores de 24 meses en Mexico [Randomized clinical trial and pharmacoeconomic analysis of the impact of racecadotril (Hidrasec ${ }^{\mathbb{R}}$ ) as an adjuvant in the treatment of acute gastroenteritis on the reduction of hospital related expenses in infants under 24 months in Mexico]. Rev Invest Clin. 2013. In press. Spanish.

17. Melendez Garcia JM, Rodriguez JT. Racecadotril en el tratamiento de la diarrea agudo en ninos [Racecadotril in the treatment of Acute diarrhea in children]. Rev.Facultad Med (Guatemala). 2007(4):25-28. Spanish.

18. Lehert P, Cheron G, Calatayud GA, et al. Racecadotril for childhood gastroenteritis: an individual patient data meta-analysis. Dig.Liver Dis. 2011;43(9):707-713.

19. Gordon M, Akobeng A. Racecadotril for acute diarrhoea in children: systematic review and meta-analyses. Arch Dis Child. 2016;101(3):234-240.

20. Youngkong S. Application of HTA research on policy decision-making. J Med Assoc Thailand. 2014;97 Suppl 5:S119-126.

21. Chaikledkaew U, Kittrongsiri K. Guidelines for health technology assessment in Thailand (second edition) - the development process. J Med Assoc Thai. 2014;97(Suppl 5):S4-S9.

22. Thamlikitkul V. Health technology assessment in developing the National List of Essential Medicines in Thailand. J Med Assoc Thai. 2014;97(Suppl 5):S4-S9.

23. Rautenberg TA, Zerwes U, Foerster D, Aultman R. Evaluating the cost utility of racecadotril for the treatment of acute watery diarrhea in children: the RAWD model. Clinicoecon Outcomes Res. 2012;4: 109-116. 
24. Drummond MF, Bloom BS, Carrin G, et al. Issues in the cross-national assessment of health technology. Int Technol Assess Health Care. 1992;8(4):671-682.

25. Thavorncharoensap M. Measurement of utility. J Med Assoc Thai. 2014;97(Suppl 5):S43-S49.

26. Thavorncharoensap M. Measurement of health outcomes. J Med Assoc Thai. 2014;97(Supp1 5):S27-S32.

27. Riewpaiboon A. Measurement of costs for health economic evaluation. J Med Assoc Thai. 2014;97(Suppl 5):S17-S26.

28. Permsuwan U, Guntawongwan K, Buddhawongsa P. Handling time in economic evaluation studies. J Med Assoc Thai. 2014;97(Suppl 5):S50-S58.

29. Chaikledkaew U. Presentation of economic evaluation results. $J$ Med Assoc Thai. 2014;97(Suppl 5):S72-S80.

30. Tanvejsilp P, Ngorsuraches S. Defining the scope of health technology assessment and types of health economic evaluation. J Med Assoc Thai. 2014;97(Supp1 5):S10-S16.

31. Limwattananon S. Sensitivity analysis for handling uncertainty in an economic evaluation. J Med Assoc Thai. 2014;97(Suppl 5): S59-S64.

32. Guarino A, Ashkenazi S, Gendrel D, Lo Vecchio A, Shamir R, Szajewska. European Society for Pediatric Gastroenterology, Hepatology, and Nutrition/European Society for Pediatric Infectious Diseases Evidence-Based Guidelines for the Management of Acute Gastroenteritis in Children in Europe: Update 2014. Available from: ttp://www. espghan.org/fileadmin/user_upload/guidelines_pdf/Guidelines_2404/ European_Society_for_Pediatric_Gastroenterology_.26.pdf. Accessed June 27, 2017.

33. Abbott Laboratories. Summary of Product Characteristics: Hidrasec 30 mg Granules for oral suspension. electronic Medicines Compendium (eMC). Available from: https://www.medicines.org.uk/emc/medicine/31233. Accessed March 13, 2017.

34. National Statistical Office (NSO). Multiple Indicator Cluster Survey 2012; Monitoring the situation of children and women; 2012. Available from: https://www.unicef.org/thailand/57-05-011-MICS_EN.pdf. Accessed March 21, 2017.
35. World Health Organization. WHO child growth standards: length/ height-for-age, weight-for-age, weight-for-length, weight-for-height and body mass index-for-age: methods and development; 2006. Available from: https://www.apps.who.int/iris/bitstream/10665/43413/1/924154 693X_eng.pdf. Accessed March 21, 2017.

36. Drug and Medical Supply Information Center Ministry of Public Health; 2017. Available from: http://dmsic.moph.go.th/dmsic/ index.php? $\mathrm{p}=1 \&$ type $=3 \& \mathrm{~s}=3 \& \mathrm{id}=\mathrm{p} \_d r u g \_n o r m a l \_e n \& l a n g=e n \&$ keyword=p\&sh=5. Accessed March 14, 2017.

37. Pharaonia Pharmaceuticals (Pharo Pharma). Summary of Product Characteristics Oral Rehydration Solution (ORS); 2015. Available from: www.nmpb.gov.sd/.../spc/.../SPC\%20Doc/Spc\%20Oral\%20Rehydration\%20Solution. Accessed February 21, 2017.

38. Freedman SB, Adler M, Seshadri R, Powell EC. Oral ondansetron for gastroenteritis in a pediatric emergency department. The New England Journal of Medicine. 2006;354(16):1698-1705.

39. Unicef. Country Data Thailand. Available from: https://www.unicef. org/infobycountry/Thailand_statistics.html. Accessed March 6, 2017.

40. Unicef. Diarrhoea treatment, the subtitle is children under 5 with diarrhea receiving oral rehydration salts - percentage 2016. Available at: https://data. unicef.org/topic/child-health/diarrhoeal-disease/. Accessed March 1, 2017.

41. Lamberti LM, Fischer Walker CL, Black RE. Systematic review of diarrhea duration and severity in children and adults in low- and middleincome countries. BMC Public Health. 2012;12:276.

42. Sakthong P. Measurement of clinical-effect: utility. J Med Assoc Thai. 2008;91(Suppl 2):S43-S52.

43. National Institute for Health and Care Excellence (NICE). Diarrhoea and vomiting caused by gastroenteritis in under $5 \mathrm{~s}$ : diagnosis and management. Clinical Guideline 84; 2009. Available from: https://www.nice. org.uk/guidance/cg84. Accessed November 20, 2016.

44. Unicef. Estimates of child cause of death, diarrhoea; 2015. Available from: https://data.unicef.org/topic/child-health/diarrhoeal-disease/. Accessed March 24, 2017.

45. Pham LT, Vu TN, Tham CD, et al . 2015. Adopting Thai diagnosis related group for Vietnam Universal Health Coverage: a case of Ba Vi District Hospital. Siriraj Med J. 2015;67:227-234. 


\section{Supplementary material}

Table SI Model adaptation Thailand: base case parameters

\begin{tabular}{|c|c|c|}
\hline \multicolumn{3}{|l|}{ Cost parameters } \\
\hline Drug costs & Value & Source \\
\hline \multicolumn{3}{|l|}{$\mathrm{R}+\mathrm{ORS}$} \\
\hline Recommended dose/administration $(\mathrm{mg} / \mathrm{kg})$ & 1.5 & SPC Thailand' \\
\hline Average weight of child $(\mathrm{kg})$ & 12.9 & $\mathrm{NSO}, \mathrm{WHO}^{2,3}$ \\
\hline Number of administrations per day (\#) & 3 & SPC Thailand' \\
\hline Number of milligrams per sachet $(\mathrm{mg})$ & 30 & SPC Thailand' \\
\hline Cost per sachet & B26.78 & Abbott Laboratories Thailand price list, data on file, December 2016 \\
\hline \multicolumn{3}{|l|}{ Oral rehydration salts } \\
\hline Recommended dose/admin $(\mathrm{mL})$ & 240 & IMS data from Abbott Laboratories, data on file, December 2016 \\
\hline Number of sachets (\#) & I & IMS data from Abbott Laboratories, data on file, December 2016 \\
\hline Cost per sachet & BI.54 & Drug And Medical Supply Information Center, Ministry of Public Health \\
\hline \multicolumn{3}{|l|}{ Outpatient care costs } \\
\hline Average cost per polyclinic visit (normal hours) & BI 42.60 & Model assumption ${ }^{c}$ \\
\hline \multicolumn{3}{|l|}{ Inpatient care costs } \\
\hline National average nonelective inpatient stay (short) & $\mathrm{B} 2,824.00$ & Sutra $^{5}$ \\
\hline
\end{tabular}

\begin{tabular}{|c|c|c|c|c|c|c|c|c|}
\hline \multicolumn{9}{|l|}{ Adverse event costs } \\
\hline Adverse event & Severity & Description & $\begin{array}{l}\text { Drug/ } \\
\text { admission } \\
\text { cost (B) }\end{array}$ & Reference $^{a}$ & $\begin{array}{l}\text { Proportion } \\
\text { of all } \\
\text { adverse } \\
\text { events }\end{array}$ & Reference $^{\mathrm{b}}$ & $\begin{array}{l}\text { Proportion } \\
\times \text { cost }\end{array}$ & $\begin{array}{l}\text { Average } \\
\text { cost }\end{array}$ \\
\hline Vomiting & Mild & Domperidone & 5.77 & $\begin{array}{l}\text { Thai National } \\
\text { Drug List }\end{array}$ & $47.5 \%$ & $\begin{array}{l}\text { Model } \\
\text { assumptionc }\end{array}$ & 2.74 & \\
\hline Vomiting & Moderate & Ondansetron IV & 15.89 & $\begin{array}{l}\text { Thai National } \\
\text { Drug List }\end{array}$ & $47.5 \%$ & $\begin{array}{l}\text { Model } \\
\text { assumptionc }^{c}\end{array}$ & 7.55 & \\
\hline Vomiting & Severe & $\begin{array}{l}\text { Gastroenteritis in } \\
\text { children }<10 \text { years } \\
\text { no cc }\end{array}$ & $\mathrm{I}, 846$ & $\begin{array}{l}\text { Thai DRG code } \\
06580^{*, 12}\end{array}$ & $5.0 \%$ & $\begin{array}{l}\text { Freedman } \\
\text { et } \mathrm{al}^{6}\end{array}$ & 92.30 & \\
\hline $\begin{array}{l}\text { Vomiting cost } \\
\text { (excluding service cost) }\end{array}$ & Average & & 0 & $\begin{array}{l}\text { Model } \\
\text { assumptionc }\end{array}$ & na & na & 102.59 & \\
\hline $\begin{array}{l}\text { Vomiting cost } \\
\text { (including service cost) }\end{array}$ & Average & & 50 & $\begin{array}{l}\text { Model } \\
\text { assumptionc }\end{array}$ & na & na & 152.59 & \\
\hline \multicolumn{2}{|l|}{ Average cost vomiting } & & & & & & & 127.59 \\
\hline Fever & Mild & $\begin{array}{l}\text { Paracetamol (supps } \\
\text { two packs at B6.90) }\end{array}$ & 13.8 & $\begin{array}{l}\text { Thai National } \\
\text { Drug List }\end{array}$ & $45 \%$ & $\begin{array}{l}\text { Model } \\
\text { assumption }\end{array}$ & 6.21 & \\
\hline Fever & Moderate & $\begin{array}{l}\text { Paracetamol (supps } \\
\text { two packs at B6.90) }\end{array}$ & 13.8 & $\begin{array}{l}\text { Thai National } \\
\text { Drug List }\end{array}$ & $45 \%$ & $\begin{array}{l}\text { Model } \\
\text { assumptionc }\end{array}$ & 6.21 & \\
\hline Fever: severe & Severe & $\begin{array}{l}\text { Gastroenteritis in } \\
\text { children }<10 \text { years } \\
\text { no cc }\end{array}$ & $\mathrm{I}, 846$ & $\begin{array}{l}\text { Thai DRG code } \\
06580^{*, 12}\end{array}$ & $10 \%$ & $\begin{array}{l}\text { Model } \\
\text { assumptionc }\end{array}$ & 184.60 & \\
\hline $\begin{array}{l}\text { Fever cost (excluding } \\
\text { service cost) }\end{array}$ & Average & & 0 & $\begin{array}{l}\text { Model } \\
\text { assumptionc }^{c}\end{array}$ & na & na & 197.02 & \\
\hline $\begin{array}{l}\text { Fever cost (including } \\
\text { service cost) }\end{array}$ & Average & & 50 & $\begin{array}{l}\text { Model } \\
\text { assumption }^{c}\end{array}$ & na & na & 247.02 & \\
\hline Average cost fever & & & & & & & & 222.02 \\
\hline Drug allergy & Mild & Hydroxyzine & 8.92 & $\begin{array}{l}\text { Thai National } \\
\text { Drug List }\end{array}$ & $45 \%$ & $\begin{array}{l}\text { Model } \\
\text { assumptionc }\end{array}$ & 4.01 & \\
\hline
\end{tabular}


Table SI (Continued)

\begin{tabular}{|c|c|c|c|c|c|c|c|c|}
\hline \multicolumn{9}{|l|}{ Adverse event costs } \\
\hline Adverse event & Severity & Description & $\begin{array}{l}\text { Drug/ } \\
\text { admission } \\
\text { cost }(B)\end{array}$ & Reference $^{a}$ & $\begin{array}{l}\text { Proportion } \\
\text { of all } \\
\text { adverse } \\
\text { events }\end{array}$ & Reference $^{b}$ & $\begin{array}{l}\text { Proportion } \\
\times \text { cost }\end{array}$ & $\begin{array}{l}\text { Average } \\
\text { cost }\end{array}$ \\
\hline Drug allergy & Moderate & Hydroxyzine & 8.92 & $\begin{array}{l}\text { Thai National } \\
\text { Drug List }{ }^{4}\end{array}$ & $45 \%$ & $\begin{array}{l}\text { Model } \\
\text { assumptionc }\end{array}$ & 4.01 & \\
\hline Drug allergy & Severe & $\begin{array}{l}\text { Gastroenteritis in } \\
\text { children }<10 \text { years, } \\
\text { moderate } \\
\text { complications }\end{array}$ & 4,344 & $\begin{array}{l}\text { Thai DRG code } \\
06582^{* *, 12}\end{array}$ & $10 \%$ & $\begin{array}{l}\text { Model } \\
\text { assumptionc }\end{array}$ & 434.35 & \\
\hline $\begin{array}{l}\text { Drug allergy cost } \\
\text { (excluding service } \\
\text { cost) }\end{array}$ & Average & & 0 & $\begin{array}{l}\text { Model } \\
\text { assumption }\end{array}$ & na & na & 442.38 & \\
\hline $\begin{array}{l}\text { Drug allergy cost } \\
\text { (including service cost) }\end{array}$ & Average & & 50 & $\begin{array}{l}\text { Model } \\
\text { assumption }\end{array}$ & na & na & 492.38 & \\
\hline $\begin{array}{l}\text { Average cost drug } \\
\text { allergy }\end{array}$ & & & & & & & & 467.38 \\
\hline
\end{tabular}

\begin{tabular}{|c|c|c|}
\hline Other parameters & Parameter value & Reference \\
\hline \multicolumn{3}{|l|}{ Outpatient care } \\
\hline Proportion on ORS: diarrhea resolves at 48 hours & $26 \%$ & Lehert et $\mathrm{al}^{7}$ \\
\hline Proportion on R+ORS: diarrhea resolves at 48 hours & $58 \%$ & Lehert et al ${ }^{7}$ \\
\hline \multicolumn{3}{|l|}{ Inpatient care } \\
\hline Proportion on ORS: referred for inpatient stay at 48 hours & $36 \%$ & Alvarez Calatayud et al ${ }^{8}$ \\
\hline Proportion on R+ORS: referred for inpatient stay at 48 hours & $6 \%$ & Alvarez Calatayud et $\mathrm{al}^{8}$ \\
\hline \multicolumn{3}{|l|}{ Adverse events } \\
\hline Proportion on ORS: experiencing AEs & $16 \%$ & Baumer and Joulin 9 \\
\hline Proportion on R+ORS: experiencing AEs & $12 \%$ & Baumer and Joulin9 \\
\hline \multicolumn{3}{|l|}{ Adverse event frequency } \\
\hline \multicolumn{3}{|l|}{$\mathrm{R}+\mathrm{ORS}$} \\
\hline Vomiting & $5.1 \%$ & Baumer and Joulin9 \\
\hline Fever & $2.3 \%$ & Baumer and Joulin9 \\
\hline Allergic $\mathrm{AE}$ & $1.3 \%$ & Baumer and Joulin 9 \\
\hline \multicolumn{3}{|l|}{ ORS (or placebo) } \\
\hline Vomiting & $5.8 \%$ & Baumer and Joulin' \\
\hline Fever & $4.6 \%$ & Baumer and Joulin 9 \\
\hline Allergic $A E$ & $1.4 \%$ & Baumer and Joulin 9 \\
\hline \multicolumn{3}{|l|}{ Quality of life (utility) } \\
\hline Average QoL $<5$ years: primary care/outpatient setting & 0.7345 & Martin et al ${ }^{10}$ \\
\hline Average QoL $<5$ years: secondary care/inpatient setting & 0.6145 & Martin et al ${ }^{10}$ \\
\hline Average QoL: “well” person (no diarrhea) & 0.9400 & Kind et al'" \\
\hline
\end{tabular}

Notes: *DRG code 06580 gastroenteritis children $<10$ years no $c c$ (inside $U C=B 2,136$, outside $U C=B 1,557$, average $B 1,846$ ). **DRG code 06582 gastroenteritis children $<10$ years with moderate complications (inside $U C=B 5,024$; outside $U C=B 3,663$, average $=\mathbb{B} 4,343$ ). ${ }^{2}$ The first reference column refers to the data in the "Drug/admission cost" column. 'The second reference column refers to the data in the "Proportion of all adverse events" column. "Model assumptions have no source or reference.

Abbreviations: AE, adverse event; cc, comorbidities and complications; DRG, diagnosis related group; IMS, IMS Health; IV, intravenous; na, not available; NSO, National Statistical Office; ORS, oral rehydration solution; QoL, quality of life; R, racecadotril; SPC, summary of product characteristics; supps, suppositories; UC, universal coverage; WHO, World Health Organization.

\section{References}

1. Hidrasec Paediatric. Summary of Product Characteristics. Thailand: Abbott Laboratories; 2015.
2. National Statistical Office (NSO). Multiple Indicator Cluster Survey 2012; Monitoring the situation of children and women; 2012. Available from: https://www.unicef.org/thailand/57-05-011-MICS EN.pdf. Accessed March 21, 2017. 
3. World Health Organization. WHO child growth standards: length/ height-for-age, weight-for-age, weight-for-length, weight-for height and body mass index-for-age: methods and development; 2006. Available from: http://apps.who.int/iris/bitstream/10665/43413/1/9241546 93X_eng.pdf. Accessed March 21, 2017.

4. Ministry of Health. Thai National Drug List Average Value; 2016. Available from: www.dmsic.moph.go.th/dmsic/index. php? $=1 \&$ type=3\&s=3\&id=middle drug. Accessed March 14, 2017.

5. Sutra S, Kosuwon P, Chirawatkul A, Thepsuthammarat K. Burden of acute, persistent and chronic diarrhea, Thailand, 2010. J Med Assoc Thai. 2012;95(Suppl 7):S97-S107.

6. Freedman SB, Adler M, Seshadri R, Powell EC. Oral ondansetron for gastroenteritis in a pediatric emergency department. $N$ Engl J Med. 2006;354(16):1698-1705.

7. Lehert P, Cheron G, Calatayud GA, et al. Racecadotril for childhood gastroenteritis: an individual patient data meta-analysis. Dig Liver Dis. 2011;43(9):707-713.
8. Alvarez Calatayud E, Pinei Simon G, Taboada Castro L, et al. Efectividad de racecadotrilo en el tratamiento de la gastroenteritis aguda [The effectiveness of Racecadotril in the treatment of acute gastroenteritis]. Acta Pediatr Esp. 2009;67(3):117-122. Spanish.

9. Baumer P, Joulin Y. Pre- and postmarketing safety profiles of Racecadotril sachets, a "new" antidiarrhoeal drug. J Pediatr Gastroenterol Nutr. 2009;48(Suppl 3):E99.

10. Martin A, Cottrell S, Standaert B. Estimating utility scores in young children with acute rotavirus gastroenteritis in the UK. J Med Econ. 2008;11(3):471-484.

11. Kind P, Hardman G, Macran S. UK population norms for EQ-5D. Discussion paper 172; 1999. Available from: https://www.york.ac.uk/ che/pdf/DP172.pdf. Accessed June 9, 2017.

12. Naresuan University. List of DRGs with relative weights (Thai DRG 5.0). Available from: www.med.nu.ac.th/chem/bank/TGrpV5017/TDrg40Rw. Doc. Accessed December 1, 2016.
ClinicoEconomics and Outcomes Research

\section{Publish your work in this journal}

ClinicoEconomics and Outcomes Research is an international, peerreviewed open-access journal focusing on health technology assessment, pharmacoeconomics and outcomes research in the areas of diagnosis, medical devices, and clinical, surgical and pharmacological intervention. The economic impact of health policy and health systems
Submit your manuscript here: https://www.dovepress.com/clinicoeconomics-and-outcomes-research-journal

\section{Dovepress}

organization also constitute important areas of coverage. The manuscript management system is completely online and includes a very quick and fair peer-review system, which is all easy to use. Visit http://www.dovepress.com/testimonials.php to read real quotes from published authors. 